\title{
Educational decentralization models in Latin America
}

\section{Emanuela Di Gropello}

Economic Affairs Officer, ECLAC.
Decentralization of social services is one of the central elements of the social policy reforms being carried out in Latin America in order to make the provision of such services more efficient and to strengthen the democratization processes. This article analyses the processes of decentralization of education in seven Latin American countries (Argentina, Bolivia, Brazil, Chile, Colombia, Mexico and Nicaragua). It seeks to systematize these experiences, using a theoretical typology of reform models; to present some results and trends in terms of the efficiency and equity of the provision of these services, and to extract some useful lessons for the design of future reforms. Although the models developed in the various countries differ from each other, they nevertheless have some common features: they depend on the resources provided by the central level to finance the services, and in many cases they subordinate schools to decisions taken at other levels. Among the main economic and social effects of the reforms are the limited progress made in participation and, hence, social efficiency; the ambiguous results obtained in terms of technical efficiency, and a trend which is not yet fully confirmed towards greater inter-territorial disparities in educational indicators. Among the lessons for policy formulation is the importance of giving the new levels of supply some degree of real autonomy, using a system of transfers which encourages a quest for efficiency while at the same time safeguarding equity, taking care to preserve the internal coherence of the models, giving some responsibilities directly to the schools, and ensuring that there is a suitable framework for the regulation and supervision of decentralized service supply systems. 


\section{I}

\section{Introduction}

The structural reforms carried out in Latin America during the 1980s in order to change the State's role in the economy, and the incorporation of the macroeconomic balances as a central element of economic policy after the crisis of the early 1980s, led to a new conception of public policy and especially social policy. The paternalistic conception of the State, which had led to the measurement of policy results in quantitative terms, has gradually been replaced by an approach which attaches greater importance to objectives of quality, efficiency and selectivity in public spending. The processes of privatization and decentralization of social services which are spreading throughout Latin America are perfectly in line with this new approach, as they aim to improve efficiency in the provision of these services.

In this article, we will concentrate on the processes of decentralization of basic education which are taking place in seven Latin American countries (Argentina, Bolivia, Brazil, Chile, Colombia, Mexico and Nicaragua). The analysis of these processes is made more difficult by their complexity, for decentralization promotes a new distribution of roles and powers among the existing territorial or non-territorial institutional actors and brings with it profound changes in the political/institutional, financial, community participation and other areas. In order to capture the main characteristics of this new distribution of responsibilities we have brought in a conceptual framework which also helps in comparing the processes of the different countries. Our main purpose is to describe and systematically order the decentralization models adopted in the seven countries, using this frame of analysis. We will also try to describe very briefly some of the effects the reforms have had on the efficiency and equity of the provision of services -whose improvement is the main challenge in the area of education in Latin Americaand to draw some lessons that will be useful in designing future reform models.

\section{II}

\section{The analytical framework}

Analysing the logic and consequences of decentralization is a complex matter, because of the wide variety of concepts that are involved in a reform of this type. According to Rondinelli, Nellis and Cheema (1983), decentralization may be defined as the transfer of responsibilities in the fields of the planning, management, procurement and distribution of resources from the central government and its organs to field units of governmental bodies, subordinate units or levels of the government, quasi-autonomous public authorities or corporations with a more widespread local presence, regional or functional authorities, or private voluntary non-governmental organizations. With regard to this latter category of institutions, decentralization may also be defined as a situation in which public goods and services are provided by the market in response to the express preferences of indi- viduals; in other words, privatization may also be seen as a form of decentralization. Within this broad spectrum, in this article we will only consider cases of the transfer of responsibilities from the central government to subordinate public units and to semior fully autonomous public corporations or authorities.

This definition, however, still covers many possible forms of decentralization. Generally speaking, the literature on this matter ${ }^{1}$ distinguishes three main forms which differ mainly in terms of the degree of autonomy in decision-making that the central government gives to its subnational units, but in practice it is not easy to identify real cases with one or an-

\footnotetext{
${ }^{1}$ See Rondinelli, Nellis and Cheema (1983), Klugman (1994) and Winkler (1991).
} 
other of these three forms of organization, since most such cases correspond to hybrid types which combine elements from at least two of the following three forms of decentralization:

i) Deconcentration, which is the transfer of responsibilities to lower levels, with limited decisionmaking power, within ministries or organs of the central government.

ii) Delegation, which consists of the transfer of management responsibilities in respect of certain well-defined functions to public organizations which may be situated outside the normal bureaucratic structure of the central government (public enterprises, private enterprises regulated by the public sector, authorities responsible for area development and regional planning, etc.) and which generally have semi-autonomous authority for carrying out their tasks.

iii) A form of "devolution" which consists of the transfer of management responsibilities to subnational units of the government or public units in general, clearly viewed as separate levels over which the central authorities exert little or no direct control: that is to say, which have independent authority to carry out their activities.

It is supposed that the decentralizing reform of social services should improve the efficiency of public expenditure through its impact on costs and on the results in terms of the provision of such services. Production costs could be reduced, for example, by making more intensive use of local human and material resources and promoting greater control by users over the management of the services, thereby increasing the technical (or production) efficiency of the supply. ${ }^{3}$ Such reform should lead to more flexible management, closer to local needs and preferences, which should improve the yield of services and affect both the technical ${ }^{4}$ and the social ${ }^{5}$ efficiency of their

\footnotetext{
${ }^{2}$ The term "devolution" refers to a form of decentralization with full transfer of power.

${ }^{3}$ Although decentralizing provision also means losing economies of scale and possibly increasing, at least in an initial phase, the administrative outlays needed to enable the supplier levels to begin to make effective use of their new fields of responsibility.

${ }^{4}$ Measured by comparing costs and results.

5 A good is socially efficient if its characteristics reflect the preferences of the user community. Social efficiency may be a solid argument in favour of decentralization if local preferences and needs are effectively expressed and fit in with the combination of results desired by the community.
}

provision. All in all, decentralization should make it possible to progress towards more efficient resource allocation and thus favour economic growth.

The foregoing considerations would appear to make it advisable to choose a decentralization model which gives the subnational levels full autonomy in the provision of social services, in order to take maximum advantage of the possibilities for increasing technical and social efficiency. As the goods involved are of national scope, however, there are reasons why it might be better to give subnational bodies only partial autonomy and why governments often prefer intermediate (such as deconcentration or delegation of responsibilities) and hybrid (such as "devolution" with only limited autonomy) reforms rather than more radical ones. These reasons are connected with the fact that, in a context in which the aims and preferences of the subnational units are generally different from those of the central government, or else cannot be effectively implemented at the local level, it is useful for the central level to keep open certain channels of intervention to further national interests. It is easy to see, for example, that when the different geographical areas have different endowments of human and financial resources, decentralization will further increase territorial inequity. If the government is concerned for spatial equity because it seeks geographically balanced and integrated national development, linked with the individual distribution of wealth, it will find it necessary to accompany the transfer of responsibilities with compensatory or redistributive measures. Likewise, the presence of interjurisdictional externalities in the production of public goods of this type justifies measures to ensure that they meet certain minimum standards. The probably limited technical capacity of the subnational levels and the scant community participation in local decision-making can also justify active intervention by the central levels, at least to start with.

The central government can intervene in various ways. Among the instruments available to it for this purpose, transfers between the different levels of government are undoubtedly those with the greatest potential (box 1). Other such instruments are direct restrictions on autonomy through, for example, compulsory directives, laws and statutes which regulate certain functions such as the procurement and use of resources and the administration of human resources. 


\section{Box 1}

\section{SOME FORMS OF INTERVENTION THAT CAN BE USED BY THE CENTRAL LEVEL}

Guidelines (compulsory or not) on the quality and minimum or uniform quantity of the social services provided.

Stipulation, through official orders, of a binding minimum level of per capita public expenditure on the provision of social services.

General redistributive transfers to reduce inequalities in per capita income between districts.

General transfers to make the terms on which local levels of authority can supply social services more uniform. Classic examples of such subsidies are those designed to allow the same rate of fiscal expenditure to produce the same level of services.

General transfers conditional upon fulfillment by the recipient authority of a certain level of provision of social services.

Specific transfers (for a specific sector of expenditure) conditional upon the fulfillment by the recipient authority of a certain level of provision of social services.

Source: Prepared by the author on the basis of Winkler (1994).

Indeed, the main challenge facing the central government is to ensure that the units given new responsibilities advance as efficiently as possible towards objectives consonant with the national interest, thus maximizing the advantages expected from decentralization without losing control over the final results. This challenge may be illustrated very clearly in terms of a principal/agent model in which the central level is the principal and the new supplier levels the agents, who continue to be responsible to the principal for their actions. This type of model makes it possible to analyse the specific nature of the relationship between the centre and the periphery, bringing out some of the problems of incentives that often affect this relationship, such as adverse selection and moral hazard.

The existence of asymmetrical access to information when there are different central and local objectives gives rise to a problem known as adverse selection: ${ }^{6}$ the subnational levels of government can mislead the central government about their real preferences and economic conditions, thus giving rise to an inequitable and inefficient distribution of the central resources. On the other hand, uncertainty about chance events which affect the final results of each area (macroeconomic fluctuations, for example) and which cannot be predicted by either the central or the

${ }^{6}$ This is analysed at length in Rasmusen (1989) and Kreps (1990). subnational levels, ${ }^{7}$ nor can be observed ex post by the central government, ${ }^{8}$ gives rise to another problem called moral hazard, ${ }^{9}$ which may lead subnational levels of government to put little effort into the execution of their tasks, alleging "bad luck". These two problems make intervention by the principal more difficult, since in order to overcome them it is necessary to prepare optimal contracts ${ }^{10}$ which are costly and difficult to apply in practice. In such a situation, the principal may decide to use mechanisms which will allow him to negotiate more favourable and simple contracts. The main means of reducing the magnitude of these two problems is to increase the amount of information available to the central level through closer technical supervision, the strengthening of local sources of information, the setting of in-

\footnotetext{
${ }^{7}$ If the agent could see the state of affairs before the agreement was decided, this too would be a case of adverse selection.

${ }^{8}$ That is to say, when there are different objectives and it is assumed that the efforts of the agent to produce the result cannot be seen by the principal. This is a very plausible situation in view of the difficulty of following up actions carried out by external units in small geographical areas.

${ }^{9}$ This is analysed at length in Kreps (1990), Rasmusen (1989), Rees (1985 a and b), and Hart and Holmstrom (1987).

${ }^{10}$ In which the amount of the transfers depends on the initial conditions and preferences of the agents and on the final result of the actions, in accordance with complex non-linear relations which will cause the agents to reveal the truth (in the case of adverse selection) and to choose the level of effort desired by the principal (in the case of moral hazard).
} 
termediate objectives (which are easier to follow up than the final objectives), or greater participation by the local community in judging the behaviour of the subnational unit. Alternatively -for example, when the central level lacks technical capabilities and there is no consensus on national objectives between it and the community- the government may perhaps prefer to impose direct restrictions on the autonomy of the subnational levels by transferring responsibility for only part of the total number of functions, or for only part of the responsibilities in respect of a given function, through more or less restrictive orders, laws or statutes. In the final analysis, it is the combination between the need for intervention by the central level to safeguard national interests and the difficulties that such intervention involves because of the differences of objectives and the asymmetrical access to information between the agents and the principal which explains why there are so many social service decentralization models which take a somewhat weak rather than a radical approach.

The degree of autonomy effectively granted to the subnational levels in the provision of services will vary according to the frequency and intensity of direct restrictions, incentives for particular forms of behaviour $^{11}$ or other control mechanisms. In view of the foregoing, the list of types of theoretical models given at the beginning of this section is too restrictive to take proper account of these differences. In order to facilitate a classification according to the degree of autonomy and incorporate more explicitly aspects relating to community participation in decisions on the provision of services and the number of recipient levels involved, we will now add two new categories of models which come somewhere between the "devolution" and deconcentration models and we will also make a change -often made in practice- in the definition of one of the existing types. The resulting classification may be somewhat arbitrary, but it will be useful for arranging in order the various actual cases to be discussed below. This classification introduces:

i) A category of low-intensity principal/agent models -i.e., hybrid "devolution" models- which basically involve a form of "devolution" in which the

${ }^{11}$ In the shape of general or specific financial transfers allocated in line with predetermined criteria or depending on the recipient's behaviour. central level continues to finance a substantial part of the provision of social services but the subnational levels nevertheless have a high or very high degree of autonomy in all the main functions involved in such provision. Thus, there is still a relation with the central level, although it is only slight.

ii) A category of medium-intensity principal/ agent models in which the subnational levels have a relatively high degree of independence in almost all the main functions but continue to be responsible to the central level for their actions to a significant extent, because of a financing structure which is highly dependent on that level and because they are subject to quite strong rules and incentives laid down by it. These models are noteworthy for the difficult balance between autonomy and control involved in the relationship between the central and sub-central actors.

iii) A category of high-intensity principal/agent models -i.e., deconcentration models- which involve the transfer of responsibilities to levels which are also outside the ambit of the central level. This type of model has many direct restrictions on the decision-making powers transferred.

Another two aspects which must be taken into account when describing a decentralization process are: the last level affected by the reform (the intermediate level, ${ }^{12}$ the local level, ${ }^{13}$ or the service-producing unit itself) and the degree of participation in decision-making effectively attained by the local community. For example, a reform which involves the service-producing unit (hospital, school) and the user community by transferring substantive decision-making responsibility to them goes deeper than a reform which is on a level of supply that is more distant from users and does not create the mechanisms (forms of participation, use of demand subsidies, etc.) needed to enable them to control the quality of the services provided and to express their own preferences. Another important aspect is the existence of more than one subnational level responsible for providing the service. ${ }^{14}$ When this is the case, there may be problems of coordination and allocation of responsibilities that must be taken into account.

\footnotetext{
12 This usually means states (in federal countries), provinces or departments.

13 This means the municipalities.

14 This refers to cases of co-responsibility between two or more levels. It does not include marginal participation by different levels.
} 
In the case of the principal/agent model described earlier, a reform in which major responsibility for the provision of services is allocated jointly to two or more subnational levels which must operate in a complementary manner would constitute a model with a principal and two or more agents. ${ }^{15}$ If a reform gives the local community a major role in decisions on the provision of services, as for example regarding different combinations of expenditures or the ap- pointment of upper management personnel, it could be identified with a model with one agent and two principals (the central government and the community). When the central level gives the subnational levels almost complete autonomy in the provision of services, representing a "devolution" model, this would be a model in which the only principal would be the community; that is to say, it would be a model with local fiscal decisions.

\section{III}

\section{Decentralization models in education}

Most of the Latin American countries are in the process of decentralizing their basic ${ }^{16}$ or primary educational services. Some of them are doing this for more or less political motives (legitimation of the State, control of conflictive situations, democratization), others for fiscal reasons (reduction of the size and cost of the central administration, encouragement of indirect privatization processes), others for reasons of efficiency, and still others for a combination of these motives. Decentralization of educational services, like that of primary health services, is undoubtedly a megatrend in the region.

The present state of the provision of educational services in the seven countries analysed here is the result of reforms that have generally been of an ongoing but often non-linear nature which have transferred responsibility for the provision of such services to territorial subnational levels (intermediate or local government levels) or non-territorial public units (the educational establishments themselves). Among the reforms, some are of the first generation, begun in the 1980s or even before, while others are second-generation reforms begun in the early 1990s. Table 1 shows the educational decentralization episodes for each of the countries analysed. The different initial socioeconomic and political/institutional conditions of each country and the different motives

\footnotetext{
${ }^{15}$ Understood as different categories of agents. In a decentralization process, the model applied naturally involves multiple agents anyway, affecting the intensity of the problems of incentives and of the design of the transfer contracts.

${ }^{16}$ Here, basic education is understood as primary plus secondary education.
}

they have had for undertaking the reform process have led to decentralized systems which differ in the degree of autonomy they have given to the subnational, territorial and institutional levels when transferring responsibilities and in the degree of community participation in decision-making.

The present configuration of the countries' decentralized educational service systems in these three levels -subnational, territorial and institutional- is shown in figure 1 , which takes account only of the main models and tendencies, leaving out cases with little national coverage.

In order to measure these dimensions effectively, the provision of educational services has been divided into four main areas covering the main functions involved: i) the function of leading, regulating and supervising the sector; ii) the financing function; iii) the function of the direct management of the service, which involves both current management, with emphasis on personnel policy, and investment management, and iv) the "planning" function, which refers to all the decisions on content in the educational field, especially those referring to educational goals and the teaching and curricular aspects of education (fixing of the school timetables and schedules, specific goals in respect of coverage and quality, study curricula, etc.).

Sections $A$ to $G^{17}$ of figure 1 summarize, for each of the countries analysed, the participation of the central level, of the subnational levels -which include the intermediate level, the local level and the

\footnotetext{
${ }^{17}$ A summary and simplified version of the tables given in $\mathrm{Di}$ Gropello (1997).
} 
TABLE 1

Latin America (seven countries): Some examples of decentralization of education

\begin{tabular}{|c|c|c|}
\hline Country & $\begin{array}{l}\text { Starting } \\
\text { date }\end{array}$ & Description \\
\hline \multirow[t]{2}{*}{ Argentina } & 1978 & $\begin{array}{l}\text { Transfer of responsibility for management of primary educational establishments to the } \\
\text { provinces. }\end{array}$ \\
\hline & 1992 & $\begin{array}{l}\text { Transfer of responsibility for management of secondary educational establishments to the } \\
\text { provinces. }\end{array}$ \\
\hline Bolivia & 1994 & $\begin{array}{l}\text { The Popular Participation Law, adopted in } 1994 \text {, and the Administrative Decentralization } \\
\text { Law (1995) transfer respectively the physical infrastructure of basic education to the mu- } \\
\text { nicipalities and responsibility for human resources management and planning to the de- } \\
\text { partments. }\end{array}$ \\
\hline Brazil & No exact date & $\begin{array}{l}\text { State and municipal primary education systems have formally existed since } 1930 \text {. Since } \\
1970 \text { the municipalization of primary education has been further intensified and since the } \\
\text { mid-1980s the autonomy of the schools has been increased in nearly } 50 \% \text { of the states. }\end{array}$ \\
\hline Chile & 1981 & $\begin{array}{l}\text { Transfer to the municipalities of responsibility for the management of basic educational es- } \\
\text { tablishments. }\end{array}$ \\
\hline Colombia & 1991 & $\begin{array}{l}\text { With the } 1991 \text { Constitution, the main responsibility for planning and human resources } \\
\text { management in basic education was transferred to the departments and the municipalities } \\
\text { were made responsibility for the physical infrastructure of the schools. }\end{array}$ \\
\hline Mexico & 1992 & $\begin{array}{l}\text { Responsibility for the management of basic educational establishments was transferred to } \\
\text { the states. }\end{array}$ \\
\hline Nicaragua & 1993 & $\begin{array}{l}\text { Establishment of "autonomous centres" for primary and secondary education, with the } \\
\text { centres receiving broad responsibilities for the provision of services. In } 1997 \text { this process } \\
\text { covered } 50 \% \text { of secondary educational centres and } 13 \% \text { of the primary educational centres. }\end{array}$ \\
\hline
\end{tabular}

Source: Prepared by the author.

educational establishments (production units) themselves- and of the community (through community or user organizations) in the responsibility for these different functions. This summary makes it possible not only to identify the levels receiving the functions transferred and to see whether the processes give the community a place in decision-making, but also, by showing the number of levels involved in each of the functions, to determine the degree of concentration of responsibility for each function; it thus gives an (albeit only partial) indication of the degree of autonomy of the subnational levels in the provision of educational services. In order to make a full appraisal of the degree of autonomy granted, this information must be supplemented with detailed data on the role of each of the levels in the function in question, in order to determine their relative importance in the decision-making process. Thus, for example, the degree of autonomy of the local level in the financing of the services depends not only on the participation of other levels in this function but also on the relative weight of the local level's own resources compared with those coming from other levels, the degree of decentralization of the execution of expenditure ${ }^{18}$ and -a very important factor- the conditions governing the use of the resources transferred for budgetary execution. Likewise, as regards human resources management, if the sub-function of hiring staff is fully decentralized and only wage negotiations are still centralized, the subnational level's degree of autonomy will be quite different from what it would be if hiring itself were still partly centralized.

Table 2 provides information on the financing structure and human resources management: the two functions which most differ from one country to another, depending on the degree of autonomy granted. Decisions on educational content are generally shared by the various levels, with the central level

\footnotetext{
18 The local level's own resources may represent only a small fraction of total resources, but most of the latter may have been transferred to the local level for it to manage.
} 
FIGURE 1

Latin America (seven countries): Summary of the prevailing models and trends in the decentralization of education ${ }^{a}$

A. Argentina

\begin{tabular}{|c|c|c|c|c|c|}
\hline & \multirow{2}{*}{ L,R,S } & \multirow{2}{*}{$\mathrm{F}$} & \multicolumn{2}{|c|}{$\mathrm{A}$} & \multirow{2}{*}{$\mathrm{P}$} \\
\cline { 4 - 5 } & & & $\mathrm{HR}$ & $\mathrm{O}$ & \\
\hline $\mathrm{CL}$ & & & & & \\
\hline $\mathrm{IL}$ & & & & & \\
\hline LL & & & & & \\
\hline PU & & & & & \\
\hline $\mathrm{C}$ & $\mathrm{T}$ & & & & $\mathrm{T}$ \\
\hline
\end{tabular}

C. Brazil

\begin{tabular}{|c|c|c|c|c|c|}
\hline \multirow{2}{*}{} & \multirow{2}{*}{ L,R,S } & \multirow{2}{*}{$\mathrm{F}$} & \multicolumn{2}{|c|}{$\mathrm{A}$} & \multirow{2}{*}{$\mathrm{P}$} \\
\cline { 4 - 5 } & & & $\mathrm{HR}$ & $\mathrm{O}$ & \\
\hline $\mathrm{CL}$ & & & $\mathrm{T}$ & & \\
\hline $\mathrm{IL}$ & & & & & \\
\hline LL & & & & & \\
\hline $\mathrm{PU}$ & & & & & \\
\hline $\mathrm{C}$ & $\mathrm{T}$ & & & & \\
\hline
\end{tabular}

E. Colombia

\begin{tabular}{|c|c|c|c|c|c|}
\hline \multirow{2}{*}{} & \multirow{2}{*}{ L,R,S } & \multirow{2}{*}{$\mathrm{F}$} & \multicolumn{2}{|c|}{$\mathrm{A}$} & \multirow{2}{*}{$\mathrm{P}$} \\
\cline { 4 - 5 } & & & $\mathrm{HR}$ & $\mathrm{O}$ & \\
\hline $\mathrm{CL}$ & & & & & \\
\hline $\mathrm{IL}$ & & & & & \\
\hline LL & & & & & \\
\hline PU & & & & $\mathrm{T}$ & \\
\hline $\mathrm{C}$ & $\mathrm{T}$ & & & $\mathrm{T}$ & \\
\hline
\end{tabular}

G. Nicaragua

\begin{tabular}{|c|c|c|c|c|c|}
\hline \multirow{2}{*}{} & \multirow{2}{*}{ L,R,S } & \multirow{2}{*}{$\mathrm{F}$} & \multicolumn{2}{|c|}{$\mathrm{A}$} & \multirow{2}{*}{$\mathrm{P}$} \\
\cline { 4 - 5 } & & & $\mathrm{HR}$ & $\mathrm{O}$ & \\
\hline $\mathrm{CL}$ & & & & & \\
\hline $\mathrm{IL}$ & & & & & \\
\hline LL & & & & & \\
\hline PU & & & & & \\
\hline $\mathrm{C}$ & & & & & \\
\hline
\end{tabular}

B. Bolivia

\begin{tabular}{|c|c|c|c|c|c|}
\hline & \multirow{2}{*}{$\mathrm{L}, \mathrm{R}, \mathrm{S}$} & \multirow{2}{*}{$\mathrm{F}$} & \multicolumn{2}{|c|}{$\mathrm{A}$} & \multirow{2}{*}{$\mathrm{P}$} \\
\cline { 4 - 5 } & & & $\mathrm{HR}$ & $\mathrm{O}$ & \\
\hline $\mathrm{CL}$ & & & & & \\
\hline $\mathrm{IL}$ & & & & & \\
\hline $\mathrm{LL}$ & & & & & \\
\hline $\mathrm{PU}$ & & & & & \\
\hline $\mathrm{C}$ & & & & & $\mathrm{T}$ \\
\hline
\end{tabular}

D. Chile

\begin{tabular}{|c|c|c|c|c|c|}
\hline \multirow{2}{*}{} & \multirow{2}{*}{$\mathrm{L}, \mathrm{R}, \mathrm{S}$} & \multirow{2}{*}{$\mathrm{F}$} & \multicolumn{2}{|c|}{$\mathrm{A}$} & \multirow{2}{*}{$\mathrm{P}$} \\
\cline { 4 - 5 } & & & $\mathrm{HR}$ & $\mathrm{O}$ & \\
\hline $\mathrm{CL}$ & & & & & \\
\hline $\mathrm{IL}$ & & & & & \\
\hline LL & & & & & \\
\hline $\mathrm{PU}$ & & & & $\mathrm{T}$ & \\
\hline $\mathrm{C}$ & & & & $\mathrm{T}$ & \\
\hline
\end{tabular}

F. Mexico

\begin{tabular}{|c|c|c|c|c|c|}
\hline \multirow{2}{*}{} & \multirow{2}{*}{$\mathrm{L}, \mathrm{R}, \mathrm{S}$} & \multirow{2}{*}{$\mathrm{F}$} & \multicolumn{2}{|c|}{$\mathrm{A}$} & \multirow{2}{*}{$\mathrm{P}$} \\
\cline { 4 - 6 } & & & $\mathrm{HR}$ & $\mathrm{O}$ & \\
\hline $\mathrm{CL}$ & & & & & \\
\hline $\mathrm{IL}$ & & & & & \\
\hline LL & & & & & \\
\hline $\mathrm{PU}$ & & & & & \\
\hline $\mathrm{C}$ & & & & & \\
\hline
\end{tabular}

Source: Prepared by the author on the basis of Carciofi, ed. (1996), Ruiz-Mier and Giussani (1997), Draibe (1998), FUNDAP (1996), IPEA (1994), Espínola (1995), Chile, MINEDUC (1996 a and b), Vargas and Sarmiento (1997 a and b), Ornelas (1997), Castillo (1998), World Bank (1996), Fiske (1996) and Hevia (1991).

${ }^{\text {a }} \mathrm{CL}=$ central level; $\mathrm{IL}=$ intermediate level; $\mathrm{LL}=$ local level; $\mathrm{PU}$ = production unit $\mathrm{C}=$ community; $\mathrm{L}, \mathrm{R}, \mathrm{S}=$ leadership, regulation and supervision; $\mathrm{F}=$ finance; $\mathrm{A}=$ administration; $\mathrm{HR}=$ human resources; $\mathrm{O}=$ other administrative functions (current and capital management); $\mathrm{P}=$ planning; $\mathrm{T}=$ theoretical function, not yet put into practice. 
TABLE 2

Latin America (seven countries): Features of decentralized systems for the provision of education, according to various indicators

\begin{tabular}{|c|c|c|c|c|}
\hline \multirow[t]{2}{*}{ Country } & \multicolumn{3}{|c|}{$\begin{array}{l}\text { Territorial distribution } \\
\text { of finance for public } \\
\text { expenditure on basic } \\
\text { education, after trans- } \\
\text { fers between different } \\
\text { levels of government }\end{array}$} & \multirow[t]{2}{*}{ Nature of transfers and allocation criteria } \\
\hline & $\mathbf{C L}^{\mathrm{a}}$ & $\mathbf{I L}^{\mathrm{a}}$ & $\mathbf{L L}^{\mathrm{a}}$ & \\
\hline $\begin{array}{l}\text { Argentina } \\
\text { (as from } \\
\text { 1978) }\end{array}$ & 8 & $\begin{array}{l}92^{\mathrm{b}} \\
(1978- \\
1985)\end{array}$ & - & General transfers via co-sharing of taxes, allocated by law. \\
\hline $\begin{array}{l}\text { Bolivia } \\
\text { (as from } \\
\text { 1994) }\end{array}$ & 10 & $\begin{array}{c}90^{\mathrm{c}} \\
(1997)\end{array}$ & - & $\begin{array}{l}\text { Specific transfers to departments, with allocation guidelines for current ex- } \\
\text { penditure. } \\
\text { General transfers to departments and municipalities via co-sharing of taxes, } \\
\text { allocated according to size of population. Since } 1996 \text {, the resources for mu- } \\
\text { nicipalities are subject to guidelines on allocation for investment ( } 85 \% \text { of the } \\
\text { co-sharing resources must be allocated to investment). }\end{array}$ \\
\hline $\begin{array}{l}\text { Brazil } \\
\text { (as from } \\
\text { the 1970s) }\end{array}$ & 26 & 44 & $\begin{array}{l}30^{\mathrm{d}} \\
(1995)\end{array}$ & $\begin{array}{l}\text { General transfers via co-sharing of taxes, allocated according to negotiation } \\
\text { and equity criteria. } \\
\text { Specific transfers (wages-education) allocated to the states according to the } \\
\text { amount collected. Since } 1995,60 \% \text { of the total resources for education must } \\
\text { go to a fund which must spend at least } 60 \% \text { of them on wages. The resources } \\
\text { from the fund are distributed among the state and municipal schools of the } \\
\text { Nation according to the number of students enrolled. There is also a regula- } \\
\text { tion on the minimum expenditure that each municipality must make, and if } \\
\text { the fund does not manage to cover this amount the Union must pay the differ- } \\
\text { ence from its own resources. This mechanism is still only theoretical. }\end{array}$ \\
\hline $\begin{array}{l}\text { Chile (as } \\
\text { from 1981) }\end{array}$ & 50 & - & $\begin{array}{c}50^{\mathrm{e}} \\
(1991)\end{array}$ & $\begin{array}{l}\text { Specific transfers allocated according to the average attendance rate of stu- } \\
\text { dents over the last three months in each municipality and the cost of providing } \\
\text { the services. There are also redistributive cross- transfers between municipali- } \\
\text { ties (through the Common Fund for Municipalities). }\end{array}$ \\
\hline $\begin{array}{l}\text { Colombia } \\
\text { (as from } \\
\text { 1991) }\end{array}$ & 10 & 50 & $\begin{array}{c}40 \\
(1996)\end{array}$ & $\begin{array}{l}\text { General transfers to the departments (Situado Fiscal), with guidelines on allo- } \\
\text { cation to health }(25 \%) \text { and education }(75 \%) \text {, allocated according to past ex- } \\
\text { penditure, population and fiscal effort. In practice, allocation is according to } \\
\text { past expenditure. } \\
\text { General transfers to municipalities, via co-sharing of taxes, with guidelines on } \\
\text { allocation ( } 30 \% \text { for education), allocated according to past expenditure, local } \\
\text { relative poverty indicators, fiscal effort and administrative efficiency. This for- } \\
\text { mula is too complex to be effective. }\end{array}$ \\
\hline
\end{tabular}

Mexico $\quad 56 \quad 44^{\mathrm{f}} \quad \ldots \quad$ Specific transfers allocated according to an established minimum level (taking (as from (1995) account of the amount allocated the previous year) and sectoral priori1992) ties.General transfers, via co-sharing of taxes, allocated according to population and past tax collection.

Autonomous labour policy (IL).
Degree of decentralization of human resources management

Decentralized hiring (IL). Centralized

wage negotiation and

decisions on administrative staff regulations.

Autonomous labour policy (IL and LL), subject to an indicative average salary. Flexibility for hiring by the schools.

Decentralized hiring (LL) Centralized wage negotiations and administrative staff regulations.

Decentralized hiring (IL and, to a lesser extent, LL) Centralized wage negotiation and administrative staff regulations.

Responsibility for hiring shared between the central and intermediate levels. Centralized wage negotiation and administrative staff regulations.

Decentralized hiring (PU). Centralized wage negotiation and administrative staff regulations, but with a broad margin of flexibility.
(as from
68
1993)

Source: Prepared by the author on the basis of Carciofi, ed. (1996); Ruiz-Mier and Giussani (1997); Draibe (1998); Vargas and Sarmiento (1997 a and b); Ornelas (1997); Castillo (1998), and Espinoza and Marcel (1994).

${ }^{\mathrm{a}} \mathrm{CL}=$ central level (central or federal government); IL = intermediate level (states, provinces or departments); LL = local level (municipalities); PU = production unit. $\quad{ }^{b}$ Primary education. $\quad c^{c}$ Only the distribution of the central level budget for basic education is taken into account (i.e., the subnational levels' own resources are not included, nor are co-sharing resources). $\quad$ Total education (including higher education).

e The modest degree of decentralization is due mainly to the fact that public resources for the subsidized private sector are still centralized. There is a lack of data on regional resources for investment.

f Total education (including higher education). The modest degree of decentralization is due not only to the inclusion of higher education but also to the continued existence of a considerable degree of centralization in human resources hiring and the considerable size of a number of programmes (for example, for the improvement of the quality of education and promotion of science and technology) which are still centralized.

$\mathrm{g}$ Total education. Decentralized resources are provided to municipalities and schools. The figure includes own resources generated by the schools. The fact that the degree of budgetary decentralization is still low is due to the limited coverage of the process in 1996. There is a lack of more up-to-date information. 
fixing more or less flexible rules and general study plans, complemented with rules and plans submitted by the subnational levels. In Argentina, Brazil and Colombia, the subnational levels have greater flexibility, since there are only some basic binding rules.

If we look at the models shown in figure 1 , we see that there is a very wide variety of levels involved in the various functions making up the provision of services. In all cases, ${ }^{19}$ at least two levels (including the central level) share responsibility in all functions except capital management and the routine functioning of the establishments (i.e., in the management function, excluding human resources management); this shows that there is no simple dichotomy between centralized and decentralized systems but rather a variety of options. Indeed, the only common trend seen in all the systems for the provision of services is the strengthening of the regulatory role of the State (which is very necessary in a decentralized system) and the transfer of the direct management of the services to subnational levels. Depending on the combination of levels per function and the indicators shown in table $2,{ }^{20}$ it is possible to determine the degree of autonomy effectively granted to each subnational level in each aspect of the provision of services and to identify the level or levels receiving most of the responsibility for services, the magnitude of that responsibility, and its distribution among the different levels.

Summarizing all the foregoing and also taking into account the role of the community in the various aspects of the provision of services, ${ }^{21}$ we can tentatively classify the processes analysed into five major types of reforms, using the classification described in section II, which emphasizes the autonomy aspect:

i) Hybrid "devolution" processes with little participation of the top territorial level, such as the "provincialization" process in Argentina and the state and municipal systems for the provision of primary education services, operating in parallel, in Brazil. In both countries these processes provide similar proportions of decentralized resources to the subnational levels (around $90 \%$ of total resources, in

\footnotetext{
${ }^{19}$ Except Argentina, with respect to the human resources management function.

${ }^{20}$ Supplemented in the text with details of the relative weight of own resources compared with total resources.

${ }^{21}$ In order to evaluate this dimension we took into account not only the existence or absence of channels of participation but also their effective use by the community.
}

the case of primary education) and make most (or all, in the case of Argentina) of the transfers in the form of general transfers (table 2). Secondly, because of the proportions of resources generated by the supplier levels themselves, which generally represent over $40 \%$ of the total resources available in the case of education, ${ }^{22}$ they give more financial autonomy to the supplier levels than in other cases, to degrees which differ according to the guidelines for use: Argentina probably gives most freedom of decisionmaking to the intermediate level, since the Argentine provinces -unlike the Brazilian states and municipalities- are not subject to any rules on how they can use their own and co-financed resources. Thirdly, in both countries there is almost complete autonomy as regards personnel policy and a very high level of autonomy in teaching and curricular matters. With regard to participation mechanisms, in neither of the countries have the processes been participative, or at least the existing participation arrangements have not functioned effectively. However, as we shall see below, the school deconcentration process which is under way is promoting active participation within the schools.

ii) Hybrid participative "devolution" processes in the production units, that is to say, processes of the principal/agent type between an agent and two principals (the central level and the community), with only a slight relation between the agent and the central level, as for example in the school decentralization process in Nicaragua. Because of the amount of own resources generated by the schools themselves (an average of $45 \%$ of the total resources available to secondary education centres in 1996) and the high degree of autonomy they have in personnel management (appointment of headmasters, hiring and firing, wage incentives) and in teaching and curricular matters, the Nicaraguan process is close to a hybrid "devolution" process, although there are greater limitations on autonomy than in Argentina and Brazil. It can also be described as participative because of the growing importance of management councils in running the autonomous educational centres.

\footnotetext{
${ }^{22}$ Except in the case of the Brazilian municipalities, where the proportions of own resources must represent $15 \%$ to $20 \%$ of total resources. In the state of Santa Catarina, for example, in 1993 the municipalities financed an average of $20 \%$ of educational expenditure from their own resources, and the percentage is rising (FUNDAP, 1996).
} 
iii) Reforms of the principal/agent ${ }^{23}$ type, between a principal (the central level) and an agent (the intermediate or local level), with little participation (as in Chile and Mexico). In both cases these processes are marked above all by a low proportion of own resources (an average of around $10 \%$ of the total resources available for education at the supplier level), which limits the financial responsibility of the service providers but leaves them free to allocate resources without being subject to rules on expenditure or allocation. Approximately $50 \%$ to $60 \%$ of the resources destined for primary and secondary education are managed in a decentralized manner and the whole (in Chile) or most of them (in Mexico) are provided in the form of specific transfers (table 2). Wage negotiations, as well as the main aspects of teachers' career situation, are retained at the central level, while responsibility for educational content is shared between the central level and the intermediate or local levels, though the central level plays an important role in defining study plans or curricula. ${ }^{24}$ Although the Chilean model is based on municipalization and the Mexican model is based on control by the states, both of them lack effective mechanisms for local participation. In Chile, however, efforts have been made since the early 1990s to transfer responsibilities in schools throughout the country, and this should favour participation. The system of per capita subsidies for students as a means of allocating resources in that country ought to stimulate parent participation, through their choice of the school that seems best to them, but the fact that the subsidy is given to the municipality and not to the school or the students' families causes the latter to feel left out of the process of resource allocation and they continue to see education as a free public service, thus reducing the incentive to take an active part in choosing and running the schools.

iv) Reforms of the principal/agent type between a principal (the central level) and two agents (the intermediate and local levels, functioning in complementation to each other), with little participation, such as the decentralization processes in Bolivia and Colombia. These reforms are marked first of all by a co-financing system which involves two levels

\footnotetext{
${ }^{23}$ Hereafter, the principal/agent model will be understood to refer to the mid-intensity principal/agent model defined in section II.

${ }^{24}$ It may be noted that the way these functions are handled is relatively more rigid in Mexico than in Chile.
}

in addition to the supplier level (the municipality), with a similar proportion of decentralized resources in both countries (approximately 90\%), subject to quite restrictive guidelines on their use (table 2). Secondly, in both cases there is a low level of financing from local resources (approximately 5\% in Bolivia and $10 \%$ in Colombia). Thirdly, decisions on labour policy and teaching and curricular matters are shared between the supplier level and at least two other similar levels (Colombia) or depend on two similar levels which do not include the supplier level (Bolivia). In these forms of decentralization, responsibility for the provision of services is diluted among three levels and this may give rise to problems of responsibility, inter-level coordination and financial supervision. Even though both countries are promoting mechanisms to involve the local community through the creation of participation bodies, and in Colombia there is an incipient transfer of responsibilities to the school level, community participation and control continue to be weak. In Colombia, discussions are currently under way on a change in the formula for allocating resources by establishing a system of per capita allocation to make the provision of services more efficient by, inter alia, promoting greater involvement on the part of parents.

v) Processes of deconcentration involving some degree of participation of the production unit, as in the case of school decentralization in Brazil. The transfer of some categories of resources directly to the schools, which has been done since the mid-1980s in the state schools of many states, together with the appointment of headmasters by the school councils and the participation of the latter in the routine management and content of the schools, may be considered as quite an advanced form of deconcentration $^{25}$ of responsibilities in schools, with a satisfactory degree of participation by the school community in the educational process, through the councils.

Figure 2 gives a summary of the various types of educational decentralization models.

Although these reform models may seem very different from each other, a comparative analysis of them reveals some general trends. Firstly, whatever

\footnotetext{
25 The most highly advanced example of this process is that of Minas Gerais, where combined measures were taken in the early 1990s to democratize the management and strengthen the autonomy of schools in the administrative, financial and teaching areas. For a description of this process, see Guedes, Lobo and Walker (1997).
} 
the degree of decentralization of the budget and the types of transfers used, the subnational levels continue to display a high degree of financial dependence on the central level, since most of the resources still come from it, except in the state systems in Brazil. Secondly, in almost all the countries studied there are still serious rigidities in the area of human resources, due mainly to the rules on public officials which still govern the wage negotiations and career aspects and which greatly reduce the degree of autonomy in the provision of services (in all the models the teaching and curricular functions usually show greater autonomy). Thirdly, the level of community participation in decisions on the various functions involved in the provision of educational services is low (except in Nicaragua and to a rather lesser extent in
Brazil), although it is increasing in some cases. Fourthly (and this is linked with the low levels of participation), the schools are relatively absent as major actors in the decision-making processes. In almost all the countries, the reforms tend to transfer responsibilities to the intermediate and/or local levels, so that the schools are dependent on these levels in financial, administrative and teaching matters. Only in Brazil -and above all in Nicaraguahave the schools come to play a central role in the system. As noted earlier, in recent years a gradual transfer of teaching and curricular responsibilities to the schools has been embarked upon in Chile and Colombia, but these measures must be accompanied by greater administrative autonomy if they are to be really effective.

FIGURE 2

Latin America (seven countries): Types of educational decentralization models ${ }^{\text {a }}$

\begin{tabular}{|c|c|c|c|c|c|c|c|c|c|c|}
\hline & \multicolumn{3}{|c|}{ "Devolution" } & \multicolumn{3}{|c|}{ Principal/Agent } & \multicolumn{3}{|c|}{ Deconcentration } & \multirow{2}{*}{$\begin{array}{c}\text { Degree of community } \\
\text { participation }\end{array}$} \\
\hline & $\mathrm{IL}$ & LL & PU & $\mathrm{IL}$ & LL & PU & IL & LL & PU & \\
\hline Argentina & HM & & & & & & & & & Low \\
\hline Bolivia & & & & & & & & & & Incipient \\
\hline Brazil & HM & $\mathrm{HM}$ & & & & & & & & Medium (PU) \\
\hline Chile & & & & & & & & & IA & Low/Increasing \\
\hline Colombia & & & & & & & & & IA & Low/Increasing \\
\hline Mexico & & & & & & & & & & Low \\
\hline Nicaragua & & & HM & & & & & & & Medium/Increasing \\
\hline
\end{tabular}

Source: Prepared by the author.

a IL = intermediate level (province, state or department);

$\mathrm{LL}=$ local level (municipalities);

$\mathrm{PU}=$ production unit (school);

$\mathrm{HM}=$ hybrid model;

$\mathrm{IA}=$ incipient autonomy. 


\section{IV}

\section{A brief analysis of the main trends and results of the reforms}

The possibility of evaluating a reform depends on its time horizon, its depth, and the availability of reliable information for following up its results; it therefore varies from country to country, thus greatly complicating the comparative analysis of results. Furthermore, the very nature of decentralizing reforms, which are generally gradual, highly complex and involve great spatial heterogeneity, makes evaluation more difficult in any case. Finally, as the majority of the episodes analysed here took place in the early 1990s, there is not yet a sufficiently broad time horizon to make a true appraisal. Indeed, most of the experiences are so recent that only those of Chile, Argentina and Brazil lend themselves to an (albeit incomplete) evaluation of their results; in the other cases all we can do is to identify some initial trends. The appraisal should be centered on the effect of the reforms on the efficiency and equity of provision of educational services. As we saw in section II, it may be assumed that a decentralizing reform process should have a positive effect on efficiency, but in contrast equity may be at risk.

On the basis of the information presented in section III and the specific data on each of the countries analysed ${ }^{26}$ we can draw up the following balance, highly simplified for the sake of comparability:

i) The scant progress made in terms of participation in most of the countries has not permitted real advantage to be taken of the potential of the reforms for helping to raise social efficiency. ${ }^{27}$ All the countries have more or less specific channels of participa-

\footnotetext{
${ }^{26}$ Taken from Carciofi (ed.) (1996), Ruiz-Mier and Giussani (1997), Draibe (1998), Vargas and Sarmiento (1997 a and b), Ornelas (1997), Castillo (1998) and Di Gropello (1997).

27 The absence of direct information in this respect, due to the lack of periodic surveys on user satisfaction, limits the possibilities of evaluation - whatever the time horizon - to the analysis of indicators of community participation in decisions on the provision of services. It may be assumed that a satisfactory degree of participation is a necessary prior condition for achieving a satisfactory degree of social efficiency.
}

tion, but few of these have been effective. The factor which has had most influence on the degree of efficiency attained has been the initial motives behind the reforms. Thus, Nicaragua, and to a lesser extent Brazil and Bolivia, have registered most progress in participation, and this is connected with the importance attached to democratization objectives in those countries. Another factor has been the degree of financial autonomy of the new supplier levels and the degree of autonomy of the production units (as the cases of Brazil and Nicaragua show).

ii) Little information is available on the evolution of the technical efficiency of provision of educational services, as measured through cost-impact indicators, ${ }^{28}$ either because most of the reforms analysed are so recent or on account of lack of information. Only in the cases of Argentina, Brazil and Chile is there some long-term information on the evolution of indicators of this type (summarized in table 3). Generally speaking, this evolution has been of an ambiguous nature in all the cases where main responsibility for the provision of services has been transferred to subnational (intermediate or local) levels of government. In the three countries in question, for example, coverage and expenditure have followed equally marked upward or downward paths and there is not enough information on the evolution of cost-quality indicators. At all events, it does not appear that the reforms have been accompanied by tangible improvements in the productivity of expenditure. In contrast, there would appear to be a posi-

\footnotetext{
${ }^{28}$ In order to make direct measurements of technical efficiency, cost-impact indicators are used in which the impact is estimated by the effect on coverage (measured, for example, by the rate of school enrollment), quality (measured by the rate of repetition or the level of scholastic achievement) and cost (measured by indicators of expenditure or inputs). The difficulty of comparing numerators and denominators expressed in different units of measurement and establishing a causal relation with the reform under analysis suggests that these kinds of indicators should be interpreted with caution.
} 
tive evolution in cases where the decentralization has been to the schools themselves, as in the Brazilian state of Minas Gerais and -although this is a more recent experience and hence more difficult to evaluate- in Nicaragua. ${ }^{29}$ In the absence of cost-impact indicators, or in order to supplement them, positive and negative signs in terms of efficiency can be identified by using data on possible changes in the allocation and use of resources, the existence or absence of prior training conditions, the institutional development and regulation needed to ensure the success of the reforms, the degree of autonomy granted to the subnational levels, and the existing mechanisms for encouraging efficiency. Generally speaking, some positive trends are to be observed, such as some increases in investment (Bolivia, Colombia), but there are also some problems in the use and allocation of resources: for example, there have been cases of faulty utilization of the infrastructure (Bolivia) or excessive expenditure on personnel (Nicaragua, Chile), due to shortcomings in the design and application of the models.

iii) Likewise, with regard to territorial equity there is little information on the evolution of the territorial distribution of educational results and its relation with the reforms. The available analyses generally concentrate on the distribution of resources and expenditure among geographical areas resulting from the reforms, taking it as an intermediate indicator of equity. ${ }^{30}$ In the only two cases where comparable data are available for two periods sufficiently distant from one another -in Argentina and Brazilthere are indications that the dispersion of service quality between different areas has probably increased. In both countries this is related with inequitable distribution of resources among areas, in the context of the hybrid "devolution" models applied, which has increased the dispersion of intermediate indicators of the quality of education (wages, teach-

\footnotetext{
${ }^{29}$ According to a recent survey (World Bank, 1996), the various actors involved agree that the academic level of secondary education has improved in the centres which have been made autonomous. However, it would be necessary to quantify this result and compare it with the size of the resources generated by co-payment in order to draw conclusions on the productivity of the expenditure involved.

${ }^{30}$ It may be assumed that a progressive distribution of expenditure should make it possible to improve the results.
}

FIGURE 3

Argentina: Relation between GDP and expenditure per student in primary education, 1995

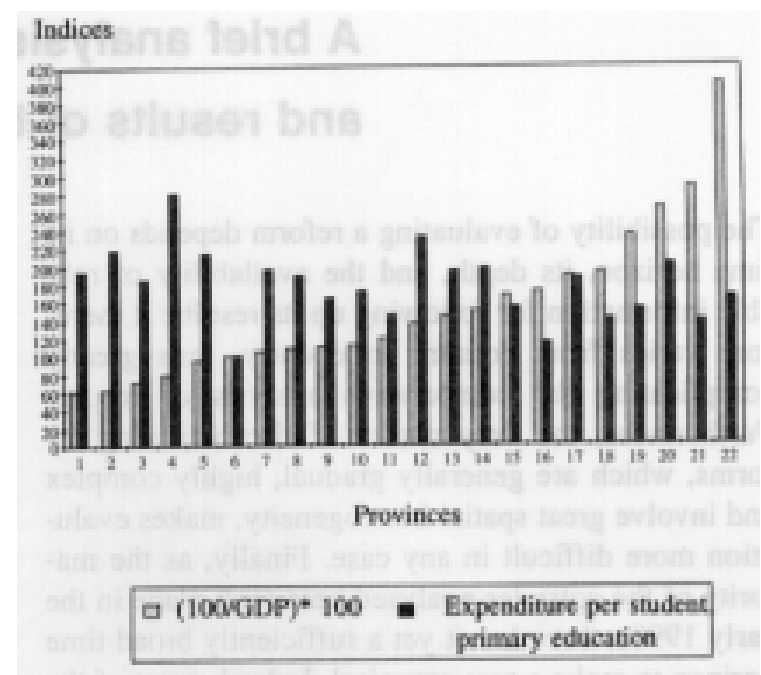

Source: Prepared by the author on the basis of Porto and Sanguinetti (1996) and Bisang and Cetrángolo (1997).

FIGURE 4

Brazil: Relation between GDP and expenditure per student on education in the municipal sector, 1990

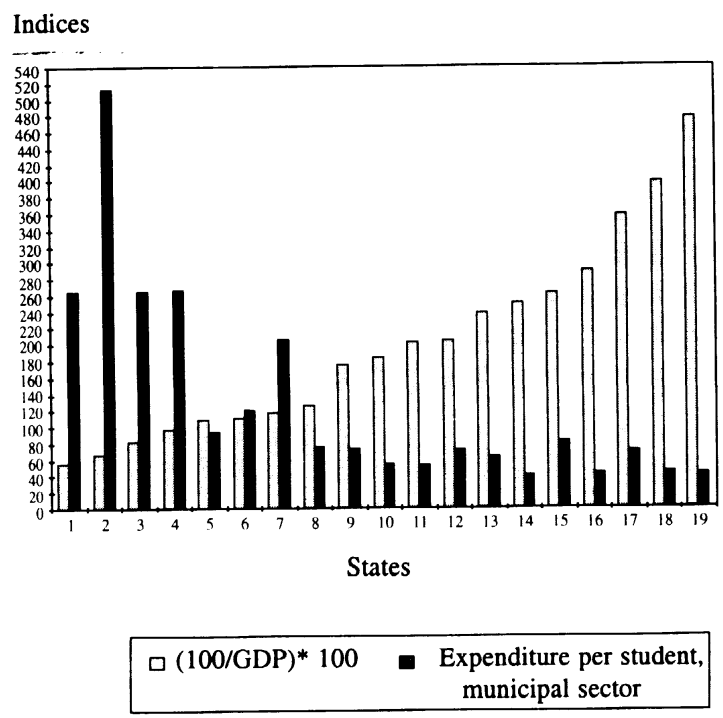

Source: Prepared by the author on the basis of Paes de Barros, Pinto de Mendonça and Shope (1993). 
TABLE 3

Latin America (three countries): Results of some of the reforms in terms of efficiency and equity

\begin{tabular}{|c|c|}
\hline Country & Technical efficiency \\
\hline Argentina & $\begin{array}{l}\text { Between } 1980 \text { and } 1991 \text {, the net rate of school enrollment } \\
\text { rose by } 6.6 \% \text {, while the percentage of the population between } \\
5 \text { and } 9 \text { years of age who had never gone to school went down } \\
\text { by } 70 \% \text {. However, expenditure on primary education went up } \\
\text { by } 85 \% \text { between the sub-periods } 1970 / 1977 \text { and } 1978 / 1985 \text {. } \\
\text { Consequently, the evolution of the cost-coverage indicators } \\
\text { for the provision of educational services is not clear. Further- } \\
\text { more, there is a lack of periodic measurements of the quality } \\
\text { of the education provided, so that it is not known how the } \\
\text { cost-quality indicators evolved. }\end{array}$ \\
\hline
\end{tabular}

Chile
Equity

After the transfer, dispersion of the average wage levels of primary school teachers trebled, favouring teachers in the provinces with higher levels of income:

$\sigma_{s}(1983)=13^{\mathrm{a}} ; \sigma_{s}(1992)=39$ and $r_{s . G D P}(1992)=0.6^{\mathrm{b}}$

This evolution, combined with the adjustments made in the size of the teaching staff by each province (in order to secure greater uniformity in terms of the number of students per teacher) would appear to have given rise to a regressive distribution of expenditure per student in primary education (eps) (figure 3):

$r_{\text {eps, } 1 / G D P}(1995)=-0.3$

and may have led to increased dispersion of quality of education $^{\mathrm{c}}$ between different areas.

There has been an increase in the dispersion of quality of education between different areas, as may be seen from the increase in the dispersion of the proportion of teachers with incomplete primary education (tip) between different areas:

$\sigma_{\text {tip }}(1980)=39 ; \sigma_{\text {tip }}(1994)=63$

which is connected with the ongoing increase in the dispersion of the average wages of teachers after the liberalization of the labour market.

The evolution of the dispersion of wage levels, combined with the adjustments in the number of teachers made by each municipality, gives rise to a regressive distribution of expenditure on education per student in the municipal sector (resps) (figure 4):

$r_{\text {reps, } 1 / G D P}(1990)=-0.6$

In spite of the positive correlation between municipal contributions and the fiscal capacity of the municipalities, the effects of decentralization on territorial equity have been limited, and in fact there is inequality of expenditure per student on education (eps) (calculated as the sum of the municipal contributions and the school subsidy from the central government) only with respect to a small number of high-income communes. If we add the compensatory expenditure programmes implemented as from the early 1990s, we even observe a slightly progressive distribution of expenditure with respect to the poverty distribution, by municipalities (p):

$r_{\text {eps.p }}(1994)=0.4$

Source: Prepared by the author on the basis of Carciofi, ed. (1996); Porto and Sanguinetti (1996); Draibe (1998); Guedes, Lobo and Walker (1997); Paes de Barros, Pinto de Mendonça and Shope (1993), and Winkler and Rounds (1993).

${ }^{\mathrm{a}} \sigma$ is the standard deviation, calculated on the basis of indices, for comparability between countries. ${ }^{\mathrm{b}} r$ is the coefficient of correlation $\left(r_{x, y}=\operatorname{Cov}(x, y) / \sigma_{x} \sigma_{y}\right) . \quad$ ' Insofar as higher average wages attract more highly trained persons and have a positive impact on teachers' attendance and motivation, a positive relation may be expected between wage levels and the quality of education.

d The reforms of the early 1980s in Chile also encouraged privatization, by giving the same public subsidies to both private and public schools. The existence of subsidized private schools is a very useful benchmark for measuring the efficiency of municipal schools.

e In 1993, as regards spending on education per student, the richest decile contributed four times more to education than the poorest decile (Winkler, 1994). $\quad \mathrm{fm}=$ educational result of the municipal sector; $\mathrm{Rp}=$ educational result of the subsidized private sector. The positive difference in performance in favour of the subsidized private schools is maintained even after taking into account the socioeconomic bias. 
FIGURE 5

Colombia: Relation between poverty and per capita share of current national income, 1996

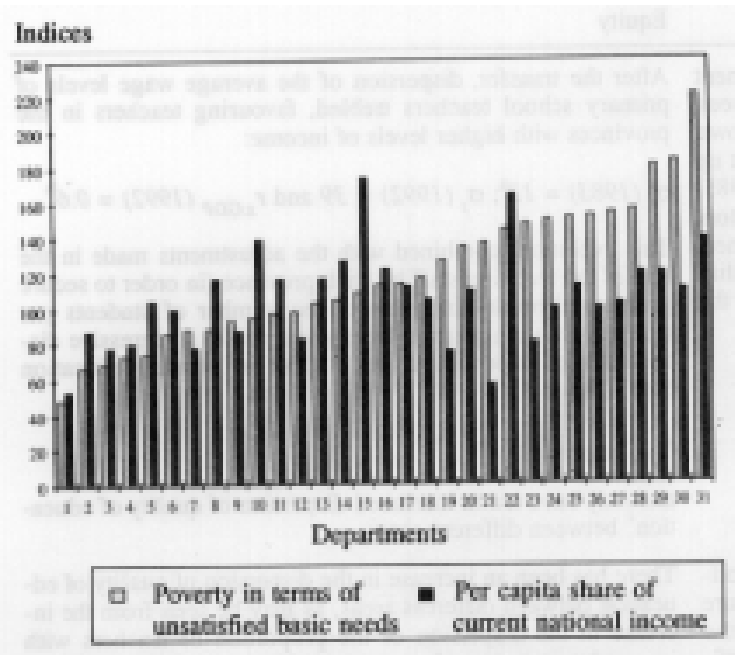

Source: Prepared by the author on the basis of Vargas and Sarmiento (1997a).

FIGURE 7

Nicaragua: Relation between poverty and per capita transfers by the central government for education, 1996

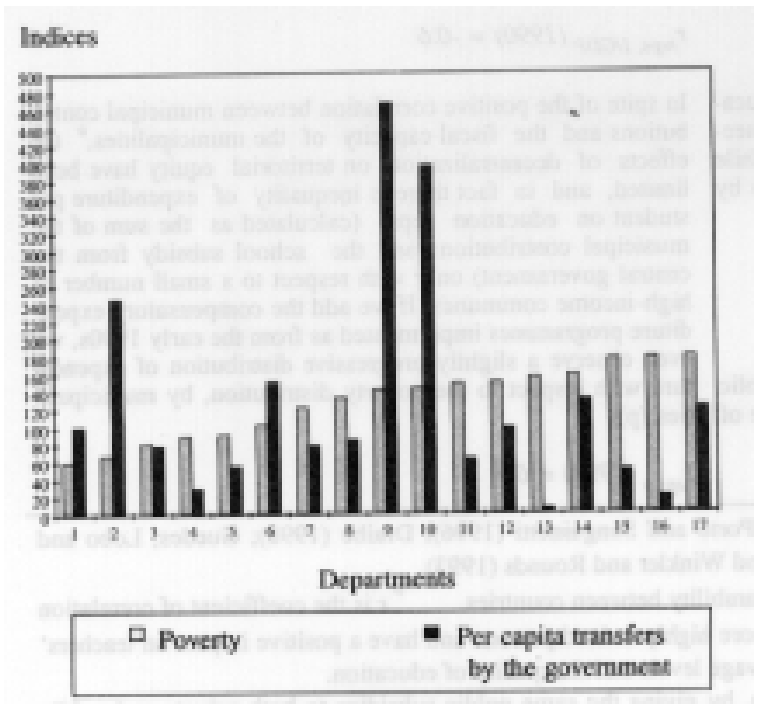

FIGURE 6

Mexico: Relation between poverty and federal
expenditure per student on basic education, 1995-1996

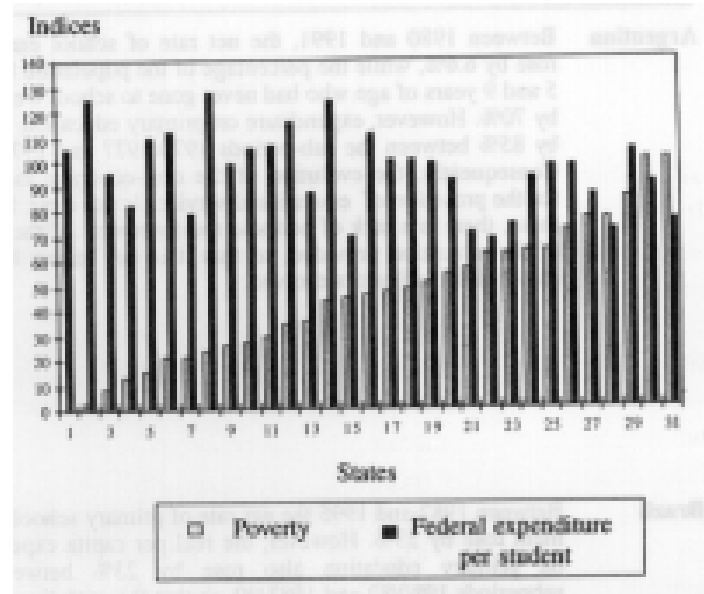

Source: Prepared by the author on the basis of Mexico, Secretaría de Educación Pública (1996) and World Bank (1992).

ers' training). In the other countries, information is only available on the territorial distribution of resources or expenditure after the reform, without any comparisons over time, serving only to detect the degree of progressiveness or regressiveness of the distribution. In three of the seven countries (Argentina, Brazil and Mexico) there would appear to be a regressive correlation between expenditure and levels of income or poverty (figures 3, 4 and 6). In another two countries (Colombia and Nicaragua) there is a lack of correlation between the transfers between different levels of government and the levels of development of each area (figures 5 and 7), which should likewise lead to a regressive territorial distribution of expenditure, because of the combination of this lack of correlation with the regressive distribution of subnational resources. Only in Chile is there a slightly progressive distribution of expenditure (table 3 ), related with the allocation and compensation mechanisms used in that country.

Source: Prepared by the author. 


\section{V}

\section{Some lessons for the design of reform models}

What may be concluded from this rapid assessment? It is not easy to draw conclusions, but the appraisal we have made indicates that the longer-term results of the reforms in terms of efficiency and equity have not generally been very satisfactory, since they show little progress in the social efficiency of social service provision and the productivity of expenditure, while the quality indicators tend to differ widely. Furthermore, the most recent tendencies are ambiguous. However, it is clear that these somewhat unsatisfactory results are due mainly to problems of design or implementation of the reforms which can be solved.

We will now try to outline some lessons ${ }^{31}$ on the design of reform models that may be drawn from the foregoing analysis:

i) The new supplier levels must be given a degree of real autonomy, minimizing the number of direct restrictions. The scant progress made by Chile in the field of efficiency, for example, is due largely to the rigidity of the model applied. The lack of labour flexibility, which is a common fault in many countries, is also a hindrance to the achievement of higher levels of efficiency.

ii) A factor of fundamental importance for the results obtained is the internal coherence of the models, especially as regards the clarity of definition of the responsibilities assigned to each level and the existence of effective coordination mechanisms. This is even more important in models based on the co-responsibility of two or more levels. In these cases there can easily be inefficiency in the use of resources (as for example in Brazil, where decisions affecting the investment/current expenditure ratio are not coordinated, giving rise to problems of overinvestment compared with the availability of staff.

iii) A crucial point for the success of the reforms is the design and implementation of financial transfers between different levels of government. As already noted in the context of decentralization reform,

${ }^{31}$ These must of course be interpreted in the light of the initial socioeconomic and politico-administrative conditions of each country. the continued existence of a significant amount of central-level finance which is distributed among the subnational levels according to socioeconomic criteria is a guarantee of equity, which may potentially be at risk with the reforms. Furthermore, when there are low levels of participation and training, transfers from the central level can significantly help to encourage options which are efficient from the technical, fiscal and social point of view. In view of the special features of the agents (the new supplier levels) and the principal (the central level), the latter should guarantee all the subnational levels a certain minimum level of financing, proportional to the initial socioeconomic conditions and local production costs (adjustment for equity), and supplement it with additional finance subject to efficiency criteria (allocation according to the results obtained in terms of coverage or quality of the services). In order to minimize the problems of adverse selection and moral hazard which may arise in situations of unequal access to information and differences of objectives between the agents and the principal, however, the central level must establish an efficient system of supervision which will make it possible to check on the efforts really made by the agents to reach the production targets, paying out the allocations according to the efficiency attained, and which will also stimulate the collection and transmission to the higher levels of information on the socioeconomic situation of the areas served by the new supplier levels, in order to facilitate allocation by equity. If this is not done, the interventions of the central level -assumed to be the remedy for the problems observed-could turn out to be as harmful as the problems themselves, or even more so.

When we review the nature of the transfers and their allocation criteria used in the first-generation reforms, we are struck by the fact that, firstly (except in Chile), specific transfers are only quite small, although they are more suitable than general transfers for meeting sectoral needs and are also necessary for linking resources with efficiency indicators. Secondly, there is a marked absence of allocation criteria 
and/or guidelines which take account of equity and technical efficiency. ${ }^{32}$ This partly explains the generally rather unsatisfactory results observed in these countries in terms of efficiency and equity. With regard to the second-generation reforms, almost all of them try to incorporate these criteria explicitly through more or less complex formulas and guidelines on expenditure or allocation. There are cases, however (Colombia, Nicaragua), where the weaknesses of the regulatory framework and lack of information make it difficult to apply the equity criteria, thus contributing to the lack of correlation between transfers and levels of poverty. In order for an incentive system to work properly it is important also to have flexible labour markets and real autonomy, so that the levels receiving the services can respond effectively to the stimuli given.

The transfer of the main areas of authority to an intermediate level or to groups of municipalities (depending on the size and population density of the geographical divisions of the country), together with decentralization of administrative, academic and financial functions to the schools themselves, should make it possible to maximize efficiency and preserve equity. The approaches at the level of individual municipalities applied in many countries, in particular, give rise to losses of economies of scale that decentralization to a higher level should be able to avoid. The gains in terms of technical and social efficiency can be maximized by giving the producer units significant degrees of autonomy, as indicated by the positive experiences in Brazil and the preliminary results in Nicaragua.

It is of fundamental importance to have a regulatory framework adapted to the regulatory and supervisory requirements of a decentralized system for the provision of educational services. Such a framework should involve the central level as well as the intermediate and local levels.
Increasing social participation and control is another great challenge of the reform process. The motivation for the promotion of democracy and the granting of greater autonomy to the producer units should have positive effects in this respect.

The reforms should be accompanied by specific training measures and programmes, especially in aspects relating to management. The lack of technical and administrative skills has adversely affected the results in Brazil and is a particularly serious problem for Bolivia and Nicaragua.

Furthermore, in view of the amounts of information needed for the functioning of the system, local bases of up-to-date information, with effective channels for its transmission, are an essential requirement.

In conclusion, the most recent reforms have had some favourable effects, such as the efforts to reduce the arbitrary allocation of transfers, to create more effective channels for participation, and to adopt approaches less focussed on the municipal level. Some of these elements have been incorporated ex post facto in reforms that were initiated at an earlier date. However, there are still some problems whose solution is a major challenge for the third-generation reforms: the limited real autonomy granted in respect of certain functions, especially human resources management; the as yet scanty development of the regulatory frameworks needed for the proper application of allocation formulas and the supervision of service provision systems; the adoption of service provision models which are hard to coordinate and regulate; the lack of autonomy of the units producing services; the lack of up-to-date information systems, and the insufficient efforts made to provide training to face the new demands posed by the provision of services.

(Original: Spanish)

\section{Bibliography}

Bisang, R. and O. Cetrángolo (1997): Descentralización de los servicios de salud en la Argentina, "Reformas de política pública" series, No. 47, Santiago, Chile, Economic Commission for Latin America and the Caribbean (ECLAC).

Carciofi, R. (ed.) (1996): Desafios de la descentralización: educación y salud en Argentina y Chile, Santiago, Chile, ECLAC.

${ }^{32}$ Although in Brazil allocation criteria incorporating aspects of efficiency and equity were recently introduced.
Castillo, M. (1998): La descentralización de los servicios de educación en Nicaragua, "Reformas de política pública" series, No. 53, Santiago, Chile, ECLAC.

Chile, MINEDUC (Ministry of Public Education) (1996a): Objetivos fundamentales y contenidos mínimos obligatorios de la Educación Básica chilena, Santiago, Chile.

(1996b): Modificación de la Ley $N^{\circ} 19.070$ que aprobó el Estatuto Docente, Santiago, Chile, September. 
Di Gropello, E. (1997): Descentralización de la educación en América Latina: un análisis comparativo, "Reformas de política pública" series, No. 57, Santiago, Chile, ECLAC.

Draibe, S.M. (1998): Avaliação da Descentralização das Políticas Sociais no Brasil: Saúde e Educação Fundamental, "Reformas de política pública" series, No. 52, Santiago, Chile, ECLAC.

Espínola, V. (1995): El impacto de la descentralización sobre la educación gratuita en Chile, "Gestión escolar" series, No. 1, Santiago, Chile, Centre for Educational Research and Development (CIDE).

Espinoza, J. and M. Marcel (1994): Descentralización fiscal: el caso chileno, "Política fiscal" series, No. 57, Santiago, Chile, ECLAC.

Fiske, E. (1996): Decentralization of Education: Politics and Consensus, Washington, D.C., World Bank.

FUNDAP (Foundation for Administrative Development) (1996): Federalismo no Brasil: descentralização e políticas sociais, São Paulo.

Guedes, A., T. Lobo and R. Walker (1997): Gestión descentralizada de la educación en el Estado de Minas Gerais, Brasil, Informe No. 11, Washington, D.C., World Bank.

Hart, O. and B. Holmstrom (1987): The theory of contracts, in Advances in Economic Theory, Fifth World Congress, London, Cambridge University Press.

Hevia, R. (1991): Política de descentralización en la educación basica y media en America Latina: estado del arte, Santiago, Chile, United Nations Educational, Scientific and Cultural Organization (UNESCO)/Information Network on Education for Latin America and the Caribbean (REDUC).

IPEA (Institute of Applied Economic Research) (1994): Gestão escolar: desafios e tendencias, "Gestion escolar" series, No. 145, Brasilia.

Klugman, J. (1994): Decentralization: A Survey of Literature from a Human Development Perspective, Occasional Paper No. 13, New York, ECLAC, Oficina del Informe Nacional de Desarrollo Humano.

Kreps, D. (1990): A Course in Microeconomic Theory, Princeton, New Jersey, Princeton University Press.

Mexico, Ministry of Public Education (1996): Informe de labores 1995-1996, Mexico City.

Ornelas, C. (1997): El proceso de descentralización de los servicios de la educación en México, Santiago, Chile, ECLAC, mimeo.
Paes de Barros, R., R.S. Pinto de Mendonça and J. A. Shope (1993): Regional Disparities in Education within Brazil: The Role of Quality of Education, Texto para discussão, No. 311, Brasilia, Institute of Applied Economic Research (IPEA).

Porto, A. and P. Sanguinetti (1996): Las transferencias intergubernamentales y la equidad distributiva : el caso argentino, "Política fiscal" series, No. 88, Santiago, Chile, ECLAC.

Rasmusen, E. (1989): Games and Information. An Introduction to Game Theory, Oxford, U.K., Basil Blackwell.

Rees, R. (1985a): The theory of principal and agent: Part 1, Bulletin of Economic Research, vol. 37, No. 1.

(1985b): The theory of principal and agent: Part 2, Bulletin of Economic Research, vol. 37, No. 2.

Rondinelli, D., J. Nellis and G. S. Cheema (1983): Decentralization in Developing Countries: A Review of Recent Experience, Staff working paper No. 581, Washington, D.C., World Bank.

Ruiz-Mier, F. and B. Giussani (1997): El proceso de descentralización y el financiamiento de los servicios de educación y salud en Bolivia, "Reformas de política pública" series, No. 48, Santiago, Chile, ECLAC.

Vargas, J. E. and A. Sarmiento (1997a): Características de la descentralización colombiana, "Reformas de política pública" series, No. 49, Santiago, Chile, ECLAC.

(1997b): La descentralización de los servicios de educación en Colombia, "Reformas de política pública" series, No. 50, Santiago, Chile, ECLAC.

Winkler, D. (1991): Decentralization in Education: An Economic Perspective, Washington, D.C, World Bank, Population and Human Resources Department (PHR).

(1994): The Design and Administration of Intergovernmental Transfers: Fiscal Decentralization in Latin America, Discussion Papers, No. 235, Washington, D.C., World Bank.

Winkler, D. and T. Rounds (1993): Municipal and Private Sector Response to Decentralization and School Choice: The Case of Chile, 1981-1990, Human Resources and Operations Policy Working Papers, No. 8, Washington, D.C., World Bank.

World Bank (1992): Mexico: The Initial Education Strategy, Report No. 10129-ME, Washington, D.C.

-(1996): Nicaragua's School Autonomy Reform: A First Look, "Impact evaluation of education reforms" series, No. 1, Washington, D.C. 